\section{International Journal \\ of \\ English Studies}

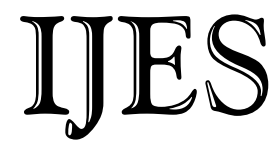

http://revistas.um.es/ijes

\title{
Performance stylistics: Deleuze and Guattari, poetry and (corpus) linguistics
}

\author{
KIERAN O'HALLORAN \\ King's College London
}

Received: 16 February 2012 / Accepted: 2 July 2012

\begin{abstract}
Taking as stimulus some key ideas of the French philosopher, Gilles Deleuze, and his collaborator the psychoanalyst, Félix Guattari, I demonstrate an alternative interpretative engagement with poetry. In this approach, a poem is seen as an invitation to the reader to be creative via a web-based, interpretative journey which is individual, edifying and refreshing. This approach allows a poem's obliqueness and suggestiveness to trigger, randomly, knowledge and resources on the world-wide-web that are new for the reader; in turn, these can be used as fresh perspectives on the poem in order to perform it in individual ways, to 'fill in' creatively personas and scenarios in the poem. This web-based engagement with a poem involves stylistic analysis.

The web-based element of performance stylistics is centrifugal, taking the reader outside of the poem, travelling from website to website. This centrifugal movement is balanced by a centripetal one which takes the reader into the patterns of the poem. Stylistic analysis meets this centripetal need effectively. Traditionally, stylistic analysis has been used to provide linguistic evidence for interpretation of a literary work. However, influenced by ideas in the work of Deleuze and Guattari, I also use stylistic analysis in a non-traditional way - to mobilise interpretation of a poem. In this article, the poem I use to demonstrate performance stylistics is Robert Frost's, 'Putting in the Seed'. Performance stylistics can draw on corpus analysis too.
\end{abstract}

\section{KEYWORDS:}

Corpus linguistics, corpus stylistics, Gilles Deleuze and Félix Guattari, poetry, rhizome, stylistics, Web.

\section{RESUMEN}

A partir de ciertas ideas clave del filósofo francés Gilles Deleuze y su colaborador, el psicoanalista Félix Guattari, ofrezco un compromiso interpretativo alternativo con la poesía. En este enfoque, un poema se entiende como una invitación a la creatividad del lector por medio de un viaje interpretativo a través de la web que es individual, edificante y estimulante. Este enfoque permite que la oblicuidad y la provocación de un poema desencadene, aleatoriamente, el conocimiento y los recursos en la web que son nuevos para el lector; a su vez, estos pueden usarse como nuevas perspectivas hacia el poema para interpretarlo de manera individual. Este compromiso implica un análisis estilístico que lleve a su interpretación

El elemento basado en la web de la estilística interpretativa es centrífugo, sacando al lector del poema, viajando de sitio web en sitio web. Este movimiento centrífugo lo equilibra otro centrípeto que introduce al lector en los patrones del poema. Esta necesidad centrípeta beneficia de manera efectiva al análisis estilístico. Tradicionalmente, el análisis estilístico se ha usado para ofrecer evidencia lingüística para la interpretación de una obra literaria. Sin embargo, influenciado por las ideas de Deleuze y Guattari, también uso el análisis estilístico de manera no tradicional -para activar la interpretación de un poema. En este artículo, el poema utilizado para demostrar la estilística interpretativa es de Robert Frost, "Plantando la semilla". La estilística interpretativa también puede beneficiarse del análisis del corpus.

\section{PALABRAS CLAVE:}

Lingüística de corpus, estilística de corpus, Gilles Deleuze, Félix Guattari, poesía, rizoma, estilística, web.

\footnotetext{
*Address for correspondence: Kieran O'Halloran. Department of Education and Professional Studies, King's College London, Waterloo Bridge Wing, Franklin-Wilkins Building, 150 Stamford Street, London, SE1 9NH. United Kingdom. E-mail: kieran.o'halloran@kcl.ac.uk
} 


\section{INTRODUCTION}

\subsection{Orientation}

A common approach to reading a poem is initially to ask 'what is this poem about?' or 'what is the poet trying to say?' and to come to a general interpretation about the poem which could be shared by others. Another conventional move is to offer a more personal interpretation of the poem and thus answer the question 'what does this poem mean to me'?

Taking as stimulus some key ideas of the French philosopher, Gilles Deleuze, and his collaborator the psychoanalyst, Félix Guattari, as well as web search engine literacy, I demonstrate an alternative interpretative engagement -one which performs a poem. It is a literacy practice where the poem is seen as an invitation to the reader to be creative via a webbased, interpretative journey which is individual, edifying and refreshing. This alternative approach puts a poem to work, allowing its obliqueness and suggestiveness to trigger, randomly, knowledge and resources on the world-wide-web that are new for the reader; in turn, these can be used as fresh perspectives on the poem in order to perform it in individual ways, to 'fill in' creatively personas and scenarios in the poem ${ }^{1}$.

Interpretation with this approach is not concerned with asking 'what is this poem about?', 'what is the poet trying to say?' nor 'what does this poem mean to me?'. Instead, the reader asks a very different question: 'How can I connect up a poem with different things outside of it in order to help dramatise it in a singular way?' With this literacy practice, the reader does not seek to form a singular interpretation of the poem itself exactly. This is because the reader's interpretative performance is across a series of connections between the poem and a number of things outside of it. This web-based engagement with a poem involves stylistic analysis in order to lead to an interpretative performance of it - I refer to this approach as performance stylistics.

\subsection{Stylistic and corpus analysis in performance stylistics}

There are two elements necessary to performance stylistics. They are employed in the following order: (i) use of the world-wide-web; (ii) stylistic analysis. The web-based element of performance stylistics is centrifugal, taking the reader outside of the poem, travelling from website to website. This centrifugal movement is balanced by a centripetal one which takes the reader into the patterns of the poem. Stylistic analysis meets this centripetal need effectively. Stylistic analysis has traditionally been used to provide linguistic evidence for interpretation of a literary work. However, influenced by ideas in the work of Deleuze and Guattari, I also use stylistic analysis in a non-traditional way -to mobilise interpretation of a poem. 
The poem I use to demonstrate performance stylistics is Robert Frost's, 'Putting in the Seed', written in 1916. I have numbered each line below; numbers in square brackets in this article refer to lines from the poem.

\section{Putting in the Seed ${ }^{2}$}

1. You come to fetch me from my work tonight

2. When supper's on the table, and we'll see

3. If I can leave off burying the white

4. Soft petals fallen from the apple tree

5. (Soft petals, yes, but not so barren quite,

6. Mingled with these, smooth bean and wrinkled pea;)

7. And go along with you ere you lose sight

8. Of what you came for and become like me,

9. Slave to a springtime passion for the earth.

10. How Love burns through the Putting in the Seed

11. On through the watching for that early birth

12. When, just as the soil tarnishes with weed,

13. The sturdy seedling with arched body comes

14. Shouldering its way and shedding the earth crumbs.

In this article, I draw on corpus analysis too for producing a performance stylistic analysis of 'Putting in the Seed'. Corpus analysis also helps the reader to mobilise interpretation but, unlike stylistic analysis, it is not a necessary part of performance stylistics. Corpus analysis in performance stylistics takes place between the web-based stage and the stylistic analysis.

In Section 2, I lay out some key interrelated ideas of Deleuze and Guattari and indicate how they inspire performance stylistics. In Section 3, I outline how stylistic analysis and corpus analysis are used in this article and how their use is also influenced by the ideas of Deleuze and Guattari. The performance stylistic reading of 'Putting in the Seed' takes place in Sections 4-8. As the reader will see, I am not advocating a 'method' for mechanically generating an interpretation of a poem. Instead, I am proposing a process which guides and facilitates experimentation out of which an individual interpretative performance can develop.

\section{HOW CONCEPTS IN DELEUZE AND GUATTARI'S WORK INSPIRE PERFORMANCE STYLISTICS}

Over more than 40 years, Gilles Deleuze (1925-1995) wrote voluminously on philosophy, literature, cinema and painting. Among his central works are Nietzsche and Philosophy (1983) and Difference and Repetition (2004). Félix Guattari (1930-1992) collaborated with Deleuze on a number of books. Probably, their most influential collaboration is A Thousand Plateaus (1987). While the work of Deleuze and Guattari has had influence in a range of disciplines in 
the social sciences and humanities, their work has yet to be taken up in a sustained manner in applied linguistics generally or more specifically in stylistics.

\subsection{Rhizome}

A key notion for performance stylistics is Deleuze and Guattari's (1987) botanical metaphor the rhizome. An actual rhizome is a horizontal, underground stem which can sprout roots or shoots from any part of its surface. Plants that have rhizomes include ginger, bamboo, orchids, Bermuda grass and poison oak. Because roots or shoots can sprout from any part of their stems, rhizomes do not have a top or bottom. This property makes them distinct from most seeds, bulbs and trees. Rhizomes also grow via subterranean networks which connect, helping to spread the plant over a large area.

Deleuze and Guattari view the rhizome as a productive image of creative thought unpredictable, growing in various directions from multiple inputs and outputs:

The rhizome operates by variation, expansion, conquest, capture, offshoots... the rhizome pertains to a map that must be produced, constructed, a map that is always detachable, connectible, reversible, modifiable, and has multiple entryways and exits and its own lines of flight (Deleuze and Guattari, 1987: 23).

The world-wide-web is a super resource for exploring knowledge rhizomatically. In relation to a poem, we can allow whatever ideas the poem triggers to move us in a variety of directions, from hyperlink to hyperlink, website to website. The rhizomatic movement helps to accrue knowledge in unpredictable manners. In turn, this can offer fresh perspectives on the poem, allowing the reader to 'fill in' the poem's personas and scenarios in surprising ways ${ }^{3}$.

\subsection{Connecting and experimenting}

Reading for Deleuze is something that sends us outside of the text to experimenting with making new connections. Deleuze (1995: 7-9) refers to this mode of reading as 'reading with love':

There are, you see, two ways of reading a book: you either see it as a box with something inside and start looking for what it signifies, [...]. And you annotate and interpret and question, and write a book about the book, and so on and on. Or there's the other way: you see the book as a little non-signifying machine, and the only question is 'Does it work, and how does it work?' How does it work for you? If it doesn't work, if nothing comes through, you try another book. This second way of reading's intensive [..., is quite different from the first, because it relates a book directly to what's Outside. A book is a little $\operatorname{cog}$ in much more complicated external machinery [...]. This intensive way of reading, in contact with what's outside the book, as a flow meeting other flows, one machine among others, as a series of experiments for each reader in the midst of events that have nothing to do with books, as tearing the book into pieces, getting it to interact with other things, absolutely anything $[. .$.$] is reading with love. That's exactly how you$ read the book. 
An 'intensive' way of reading, for Deleuze, is one which connects out to new potentials, to new ways of seeing and doing. And when he uses the term 'machine', as he does above, Deleuze refers to anything which is made of connections without an organising centre (Deleuze and Guattari, 2004). So, if a book is read 'machinically' -a term that Deleuze and Guattari employ- the reading produces a set of unpredictable connections with a series of outsides 4 .

In this article, my performance stylistic reading of 'Putting in the Seed' will connect with the following from different websites: contemporary information on a personality disorder, information on germination, a recent scientific research press release, an existing interpretation of 'Putting in the Seed', and recent sexual health advice. In the interests of rigour, I ensure that each textual resource cited carries an academic reference which I have subsequently checked. Finding productive connections with knowledge from different websites, for purposes of performance stylistics, is necessarily an experimental process.

\subsection{Becoming}

Deleuze and Guattari are less interested in states of being and more in what we can become (Deleuze and Guattari, 1987: passim). Relating a poem to our life experience is to relate a poem to what we are and what we already know -our being ${ }^{5}$. This may mean that a reader's default intuitions about a poem may not be particularly surprising. An approach which uses the poem to trigger a set of rhizomatic web searches forces the reader out of their 'being' comfort zone into new becomings, into learning new things through a set of unpredictable connections. This becoming enhances the possibility of novel perspective on a poem.

\subsection{Non-representationalism}

Deleuze highlights the limitations of a representational perspective on language, an outlook that sees a key purpose of language to describe or to represent reality. It is not so much that this key purpose is inherently misguided -it is after all how we use language much of the time. However, if we want to look at things creatively, it is limiting because representation of reality by language does not easily mobilise thinking in new directions:

Representation has only a single centre... and in consequence a false depth. It mediates everything, but mobilises and moves nothing. (Deleuze, 2004: 67)

In a nutshell, our habitual describing of reality through language is limiting for Deleuze because this representation does not easily lead to becoming and transformation.

A reading of 'Putting in the Seed' which echoes Deleuzean non-representationalism would not be 'about' someone's passion for planting seeds or 'about', say, the act of impregnation. Since these readings 'capture the reality' of the poem, 'representing' what it is 
'about', they involve no becoming. With these readings, the poem has not been used to produce new learning and mobilise thinking.

\subsection{The Untimely and context}

For Deleuze, to engage with literature, or indeed any art form, does not entail looking at how it originally responded to a particular context, but to understand its capacity to take us beyond that context. One possible approach to interpreting 'Putting in the Seed' would be to situate the reading in 1916 and assume that the poem's persona is Robert Frost, especially as he was a farmer at the time. Such a historicist reading, perhaps interesting in its own terms, would nevertheless miss the potential of 'Putting in the Seed' to be put to work to produce a reading which goes beyond this historical context. In other words, it would miss the potential for what Deleuze calls untimely effects (Deleuze, 2004: xix) ${ }^{6}$. In this article, I connect 'Putting in the Seed' to contemporary knowledge (see Section 2.1), as well as to a corpus of contemporary English, and thus take an untimely perspective on the poem.

\subsection{Flow}

A recurring image in the work of Deleuze and Guattari is flow. For them, flow is seemingly everywhere, not only air, blood, electricity, magma, sun, but conversations, culture, ideas. In discussing literature, Deleuze and Guattari specify a link between flow and style:

Style...is the moment when language is no longer defined by what it says, even less by what makes it a signifying thing, but by what causes it to move, to flow, and to explode desire. For literature is... a process and not a goal, a production and not an expression (Deleuze and Guattari, 2004: 145).

Deleuze and Guattari's images of flow and the rhizome, together with their emphasis on connection, stimulate, for me, a perspective where different elements of an interpretation flow into one another - that is, a procedure where interpretation is phased. Phasing interpretation of a poem allows different but related elements of interpretation to connect in unpredictable and thus rhizomatic ways which, in turn, can augment singular perspective. In performance stylistics, interpretation of a poem is a process of continual becoming.

\subsection{Multiplicity}

This is one of the first principles in Deleuze and Guattari (1987). A multiplicity is a whole greater than its parts. Packs, swarms, shoals, mobs or crowds are multiplicities where the qualities of the whole are different and greater than the qualities of the particular. How does this idea of multiplicity inspire performance stylistics? The phasing of different forms of knowledge garnered from the web, as a result of what the poem triggers, will facilitate the 
growth of an interpretative multiplicity. Developing an interpretative multiplicity helps to avoid an unrealistic reading of a poem which does not evoke the plural dimensions of life.

I have outlined some key ideas in the work of Deleuze and Guattari and how they inspire an approach to the interpretation of poetry. Key aspects of this literacy practice are its connective, experimental, rhizomatic and phased nature. I have so far only highlighted the web-based element of performance stylistics - the centrifugal element which propels the reader beyond the poem. To reiterate from the introduction, performance stylistics requires two elements in the following order: (i) use of the web, and (ii) stylistic analysis. Corpus analysis is an optional element which occurs between (i) and (ii). This article makes use of all three elements. In Section 3, I indicate how stylistic analysis is used centripetally in performance stylistics to take the reader back into the poem. This centripetal movement not only uses linguistic evidence to support the web-based element of a performance stylistic reading but to mobilise it too. Moreover, in Section 3, I indicate how corpus analysis can be used to mobilise interpretation also.

\section{STYLISTIC ANALYSIS AND CORPUS ANALYSIS: SUPPORTING AND MOBILISING INTERPRETATION}

\subsection{Stylistic analysis}

\subsubsection{Stylistic analysis independent of already emerged rhizomatic interpretation}

In traditional stylistic analysis of poetry, interpretation and analysis are usually synchronous. Stylistic analysis is used to support intuitions about a poem and, in turn, this analysis assists generation of interpretation in specifying it, or in explaining how the poem achieves its effects. It is my contention that this synchronous approach in stylistics can hinder singular interpretation. This is because the stylistic analysis may just reinforce, albeit systematically, default intuitions the interpreter has about the poem. The result may be a rigorous analysis, but the interpretation may not be particularly singular if the initial default intuitions are unsurprising.

In the interests of rigour, it is important to connect the emerging rhizomatic interpretation, if possible, to the patterns of the poem. Stylistic analysis can, in principle, provide empirical support for, as well as specifying, interpretation. However, crucially this stylistic analysis will be specifying rhizomatic interpretation which has already emerged independently of it, that is, previously in the web-based and corpus analysis components. As a result, this stylistic analysis stands a better chance of also mobilising interpretation than when analysis and interpretation are synchronous. 


\subsubsection{Stylistic analysis spread over different phases}

On this Deleuze and Guattari inspired approach to reading poetry, stylistic analysis takes place in different phases of interpretation. This reduces the potentially inhibiting effect on interpretation of too much linguistic description in one place -and thus potentially of too much representationalism- which in turn might hinder mobilisation of thinking. This is not to deny that a stylistic analysis should be comprehensive. But, for 'Putting in the Seed', I shall achieve reasonably comprehensive description of the poem over different phases.

\subsection{Corpus analysis}

\subsubsection{Supporting interpretation with corpus evidence}

In the last few years, corpus analysis has begun to be used to help support interpretation (and evaluation) of poetry and other literary genres (see, for instance, Adolphs and Carter, 2002; Biber, 2012; Culpeper 2009; Fischer-Starke, 2010; Hoover, 2002; Louw, 1993; Mahlberg 2007; McIntyre and Walker, 2010; O’Halloran, 2007a, 2007b; Romaine, 2010; Stubbs, 2005; Toolan, 2006). In this article, one of my uses of a corpus will be in this established sense, that is, to provide empirical support for interpretation. However, I will use a corpus in a less established sense too -to mobilise interpretation.

\subsubsection{Mobilising interpretation: Collocation}

A poem, like any text, is composed to a significant degree of different language patterns. One type of language patterning which corpus analysis reveals to be especially common is collocation -a statistically significant local association between lexical words (usually pairs of lexical words). So, for example, 'heavy' is a collocate of 'rain' in the collocations 'heavy rain' and 'the rain will be heavy today'. Investigation of a corpus is useful since it can substantiate with quantitative evidence intuitions we have about unusual collocation in a poem which, in turn, might be used to support a burgeoning interpretation.

That said, in using a large corpus to discern common collocates for a particular word, one can often find collocation which would have been difficult to predict. When a corpus search leads to unpredictable results, this discovery process could be construed as rhizomatic. In the spirit of Deleuzean and Guattarian 'flow', I will show that, if in using a corpus we find out unpredictable collocates of words or phrases in a poem, this can help evolve previously generated interpretation of the poem in the web-based stage, rather than just support it. Importantly, it would be a mobilising of interpretation which is grounded in general patterns of language use. In other words, there would be a linguistic empirical basis for the evolution of the interpretation. Moreover, since collocation analysis means necessarily going outside the language of the poem, it can be construed as non-representational. On the basis of Deleuze's position as set out in Section 2.4, a non-representational approach should aid production of a singular interpretation.

(C) Servicio de Publicaciones. Universidad de Murcia. All rights reserved. IJES, vol. 12 (2), 2012, pp. 171-199 Print ISSN: 1578-7044; Online ISSN: 1989-6131 


\subsubsection{Mobilising interpretation: Phraseology}

Language patterns can consist of both lexical words and grammatical words, e.g. 'the first time I saw'. Corpus investigation may reveal such patterns to be regular. Such regular patterns of lexical words and grammatical words, which may or may not correspond to complete grammatical units, are known as phraseologies (Hunston, 2002: 9-12; Hunston, 2010: passim). In my performance stylistic reading of Frost's poem, I also conduct a corpus analysis of phraseologies within it. In order to institute analytical consistency, when I examine phraseologies from Frost's poem in a corpus, each phraseology has only one lexical word in it, but it will have one or more grammatical words (as far as possible).

Similar to Section 3.2.2, one reason for conducting a corpus analysis of phraseologies could be to substantiate intuitions about their unusuality which, in turn, might be used to support an evolving interpretation. At other times, phraseologies might be examined for a different reason, one also indicated in Section 3.2.2: to discover collocates which otherwise are difficult to predict and thus can help mobilise interpretation -again where mobilising of interpretation is grounded in general patterns of language use, providing a linguistic empirical basis for the development of the interpretation.

\subsubsection{Corpus exploration and experimentation}

In performance stylistics, the collocates of words or phraseologies in a poem that an analyst runs with will be ones they regard as productive for progressing interpretation. Not every collocation investigation will yield interesting, surprising etc results which could be used to move interpretation along. Corpus analysis in performance stylistics is, thus, used in a less comprehensive manner than stylistic analysis, used to mobilise interpretation where this is possible. Corpus analysis is not a necessary part of performance stylistics, but a potentially productive optional component (cf Section 3.1).

\subsubsection{The 'machinic' corpus}

A corpus rigged up to search software can be construed as a 'Deleuze and Guattari machine' since it has no centre; we can start with any word / phraseology and explore its collocates or, in more 'machinic' terms, explore which words connect tightly with the search word / phraseology. It is not only the unpredictability but the particularity of the collocational connections which help excite interpretation as I shall show. Ultimately, it is the 'machinic' nature of a corpus which affords its rhizomatic potential for mobilising an interpretative performance of a poem.

In the corpus-based analysis, I draw on the 1.5 billion word corpus, $\mathrm{UKWaC}^{7}$, using Sketchengine software ${ }^{8}$. For ascertaining the statistical significance of collocation, I use tscore values. A t-score of more than two is 'normally taken to be significant' (Hunston, 2002: 72), but a t-score in double figures is very significant (Hunston, 2001: 16). Unless stated 
otherwise, I use a wordspan of $n \pm 5$ (where $n$ is the node word, i.e., the word being investigated), the standard wordspan for looking at collocations (Jones and Sinclair, 1974). Using a consistent word span helps institute rigour and comparability for different investigations of collocation.

\subsection{Connecting to an existing interpretation}

The reader will have noticed that performance stylistics involves two different types of movement: (i) evolving interpretative engagement within each phase; (ii) evolving interpretative engagement across different phases. In this article, the bulk of interpretation of 'Putting in the Seed' is done in three phases A-C (Sections 4-6), each phase employing different knowledge from world-wide-web searches.

Phases D-E (Sections 7-8) involve a different form of web connection from Phases A-C. They connect the burgeoning reading of 'Putting in the Seed' in Phases A-C to an existing interpretation of this poem randomly found on the web. One reason for this engagement is to augment rhizomatic movement by taking a different connective turn; that is, instead of connecting to a web resource indirectly related to the poem, I alter course by using one directly related to it. Another reason is to show how an existing interpretation can be regenerated (rather than plagiarised) for my own continuing performance stylistic reading of 'Putting in the Seed'. Corpus-based critique of the existing interpretation in Phase D (Section 7) will become the basis for furthering the growth of my own interpretative performance in Phase E (Section 8). This part of the procedure is, thus, 'critical-creative'. I take my cue here from the important work of Rob Pope (Pope, 2003; 2005) who argues that any critical engagement is creative and any creative engagement is critical. (Pope is a scholar inspired, in part, by the work of Deleuze.)

In what follows, I put 'Putting in the Seed' to work along the lines of the tri-partite phasal procedure presented and inspired by Deleuze and Guattari's concepts of rhizome, machinic connections, becoming, non-representationalism, untimely, flow, multiplicity. A performance stylistic reading of a poem is best seen as the following: an interpretation which moves across the poem's connections with a series of outsides rather than as an interpretation of the poem itself; the latter description evokes neither the movement of the interpretative multiplicity nor how it is dependent to a large extent on the particular emergent sequence of phases. 


\section{PHASE A: OBSESSIVE COMPULSIVE PERSONALITY DISORDER (OCPD)}

\subsection{Orientation}

For me, the first four lines of the poem suggest the poem's persona has a certain obsession with burying apple blossom. This is because they have to be fetched inside; they question whether they would be able to stop burying apple blossom instead of going into the house for supper when presumably they would be hungry. This behaviour does not strike me as particularly normal. Moreover, the persona mentions 'my work' [1] and that they are a 'slave to a springtime passion for the earth' [9]. This suggests that they are regularly in the garden and, in turn, that this seemingly obsessive behaviour may not be a unique event. Indeed, later in the poem, we learn that the poem's persona is 'watching for that early birth' [11] of a seedling -another apparently obsessive action which could well occur on different occasions. With a hunch that the behaviour of the persona could be construed as a disorder, I explored the web on search terms such as 'obsession' and 'disorder'. Consider the following criteria for judging a particular disorder: Obsessive Compulsive Personality Disorder (OCPD). These criteria are used by the 'American Psychological Association' (APA, 2000) ${ }^{9}$ :

\section{Obsessive-Compulsive Personality Disorder (OCPD)}

1. is preoccupied with details, rules, lists, order, organization, or schedules to the extent that the major point of the activity is lost;

2. shows perfectionism that interferes with task completion;

3 . is excessively devoted to work and productivity to the exclusion of leisure activities and friendships (not accounted for by obvious economic necessity);

4. is over conscientious, scrupulous, and inflexible about matters of morality, ethics, or values (not accounted for by cultural or religious identification);

5. is unable to discard worn-out or worthless objects even when they have no sentimental value;

6. is reluctant to delegate tasks or to work with others unless they submit to exactly his or her way of doing things;

7. adopts a miserly spending style toward both self and others; money is viewed as something to be hoarded for future catastrophes;

8. shows rigidity and stubbornness ${ }^{\mathbf{1 0}}$.

For an OCPD diagnosis, the person must fulfil at least four of the eight criteria (APA, 2000). Consider also this fragment of information from the same website:

\section{OCPD and men}

Obsessive-Compulsive Personality Disorder is...almost twice as prevalent in males as females (McGlashan et al., 2005). ${ }^{11}{ }^{12}$

Let me hypothesise that the persona has OCPD. How might a corpus linguistic perspective on the poem help support this idea in relation to the APA criteria? 


\subsection{Corpus-based analysis}

\subsubsection{On through the watching for that early birth [11]}

Intuitively, 'the watching for' [11] is an unusual phraseology and, indeed, it does not occur in UKWaC. When I examined collocates for 'the watching', I found that the most common collocates were 'crowd', 'audience', 'spectators', 'millions' such as in 'the watching crowd'. 'The watching' is thus used normally as a modifier of a large group of people; it is also a description of a watching separate from the describer of the event. In stark contrast, in the poem 'the watching' relates to a single person and it is their own description of what they are doing. Its unusuality points, on my reading, to a sense of detachment on the part of the persona and thus a marked concentrative focus on the task. This goes hand in hand with the marked conscientiousness of OCPD sufferers (APA Criteria 3 and 4). From corpus investigation, then, there is some initial support for the OCPD interpretation.

\subsubsection{When, just as the soil tarnishes with weed [12]}

'Tarnish' [12] is in the present tense and in conjunction with the preposition 'with'. I compared the phraseologies 'tarnishes with' and 'tarnished with' in UKWaC; there are only 2 instances of the former and 50 instances of the latter (a ratio of 1/25). In comparison, there are 207 instances of 'tarnishes' and 3441 instances of 'tarnished' (a ratio of 1/16).

This relative quantitative perspective lends support to the OCPD interpretation; would one normally notice the soil just as it tarnishes with weed? One would more likely notice the result, that something had tarnished. The persona might be said to have a marked form of empirical obsession which dovetails with the keen focus on schedule of the OCPD sufferer (APA Criterion 1) -in this case the schedule from planting seeds to seedling growth.

Let us see how stylistic analysis might further support this interpretation.

\subsection{Stylistic analysis}

\subsubsection{Morphology}

The persona's task, as indicated by the poem's title, would seem to be planting seeds. However, we never actually encounter the persona planting any seeds. Instead, the only contact with organic nature referred to is the burying of soft petals $[4,5]$. In light of the title, is the explicit burying of apple blossom in contrast to the implicit planting of seed not a little odd? We know from APA Criteria 1-2 that the perfectionism of OCPD sufferers interferes with completion of a task. Could this explicit / implicit contrast not reflect a form of task interference -the burying of apple blossom impedes the task of planting seeds (though seed planting is not, on my interpretation, the primary reason the persona is in the garden- see Section 6)? This OCPD task inference interpretation is reflected to some extent by the following: 'soft petals' $[4,5]$ is morphologically plural and mentioned twice whereas plural 
morphology is absent for 'bean' [6], 'pea' [6], 'Seed' [title, 10] and 'seedling' [13]. Indeed, one can straightforwardly construe lines [13] and [14] as focusing on just one seedling.

\subsubsection{Orthography}

'Putting in the Seed' is a particular form of lyric poem - a sonnet. A sonnet consists of 14 lines and can have different rhyme schemes. The sonnet rhyme scheme that Frost uses is close to the Petrarchan form of the sonnet ${ }^{13}$. This form consists of an octet ( 8 lines) and a sestet ( 6 lines). The delineation of the octet and sestet is indicated through a different rhyme scheme in each. A Petrarchan sonnet usually takes different perspectives in the octet and sestet (Thornborrow \& Wareing, 1998: 41); a more general, perhaps even universal perspective, is suggested in the sestet. Frost uses the sestet, seemingly, to adopt a universal position; this seems to be in relation to the capitalised 'Love' [10].

There are two full-stops in the poem. One of these is after line 14 where the poem and thus the sestet ends. While we might expect the other full-stop to come at the end of the octet, in fact it comes at the end of line 9. In viewing the sonnet as a window on the persona's mental life, the lack of 'success' in constructing the sonnet connects with the OCPD interpretation. It reflects that the persona's mind is detached and on other things, i.e., when they should be putting in seed, the burying of apple blossom interferes with this task (APA Criteria 1-2).

Using stylistic analysis, as well as corpus analysis, I have taken my first steps towards an interpretative performance of Frost's poem that the persona has OCPD. Taking my cue from the evidence in Section 4.1 that men are more likely to have OCPD than women, let me assume the persona in the poem is a man; let me also assume that the male persona is in a relationship with the person who comes to fetch him.

In Phase B, we move to a different topic in the poem: germination. That Phase B is different in knowledge content to Phase $\mathrm{A}$ is valuable from a rhizomatic perspective since attempts to connect Phase A to Phase B are less likely to be predictable. Using corpus analysis and then stylistic analysis in Phases B and C, we shall see not only the emerging interpretative performance supported by linguistic evidence, but mobilised too.

\section{PHASE B: GERMINATION}

\subsection{Orientation}

'Germination' refers to the development from seed into seedling. Researching germination in Wikipedia, I found the following: 
Seed germination depends on both internal and external conditions. The most important external factors include temperature, water, oxygen and sometimes light or darkness (Raven, Evert and Eichhorn, 2005). ${ }^{14}$

Using corpus analysis, let me see if I can connect with this information on germination so as to progress my interpretative performance of the poem.

\subsection{Corpus-based analysis}

We can assume that light, oxygen, the right soil temperature and water are extant in the scenario of the poem -otherwise the seedling in the poem would not have germinated. The first three factors can be reasonably treated as being fairly constant but the last is dependent on rain falling and/or watering by a gardener. To provide some empirical perspective on the latter, I explored the extent to which 'rain' or 'water' collocates with 'seed'. There are 60, 757 instances of 'seed' in UKWaC. To try to restrict my search to horticultural meanings of 'seed', using the Sketchengine filtering function I filtered these concordance lines on the search term, 'garden', for a wordspan of $n \pm 100$. I chose this span since a very narrow one such as $n \pm 5$ would make it unlikely I would find concordance lines where 'rain' or 'water' and 'seed' and 'garden' all featured. This filtering reduced the number of concordance lines to 5,567 . In a subsequent collocate search for 'seed' at $n \pm 5$, 'rain' did not feature but 'water' did (47 instances; t-score 6.6) ${ }^{15}$ such as in this example where 'water' is used as a verb:

Lightly rake the seed in and roll to ensure the seed comes into contact with the moisture in the soil; gently water the seed bed.

This sentence reflects how 'water' is discussed habitually in relation to germination in a garden -watering by a gardener rather than via rain. In turn, this evolves perspective on the poem. If the persona is really obsessed with the germination of the seeds, on an untimely reading of 'Putting in the Seed', why is there no evidence in the poem that he is watering since this would seem to be so habitual after planting seeds? The corpus-based evidence helps progress my interpretative performance that the poem's persona is not primarily concerned with germination, as I shall contend (see Section 6). But, for now, since watering is not signaled in the poem, the water for germination must come from rain.

Is there anything in the patterns of the poem which connects with this interpretation and can further specify and progress it?

\subsection{Stylistic analysis}

The poem is packed with voiceless sibilants ${ }^{16}$-or hissing sounds- as well as voiceless plosives. Indeed, the title itself 'Putting in the Seed' contains two voiceless plosives /p/ and /t/ 
as well as a voiceless sibilant /s/. Figure 1 shows, in Frost's poem, the voiceless plosives /p/ and $/ \mathrm{t} /$ in bold and voiceless sibilants underlined:

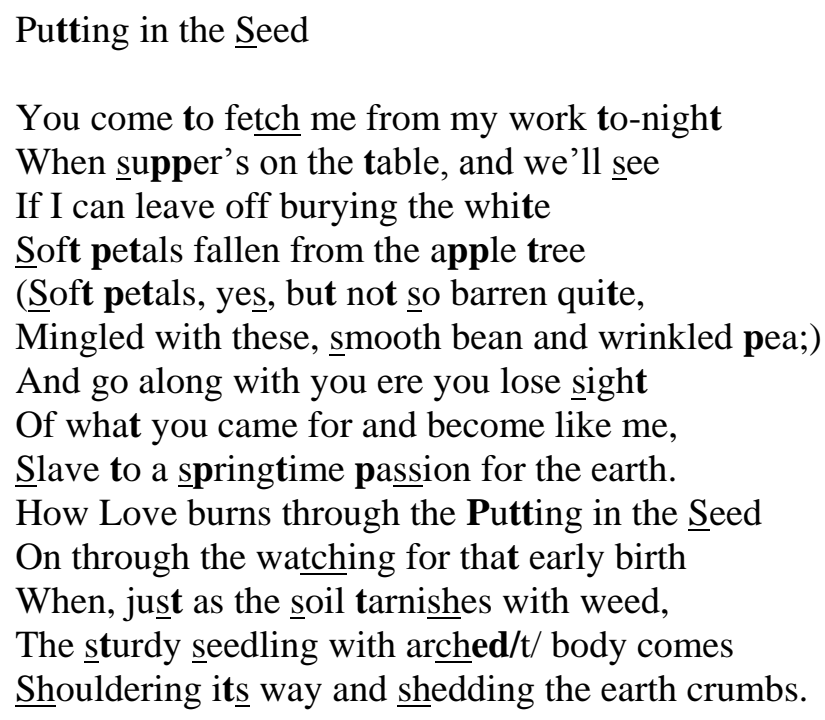

Figure 1. Voiceless plosives /p/ and /t/ (bold) and sibilants $/ \mathrm{s} /, / \mathrm{J} /, / \mathrm{t} / \mathrm{f}$ (underlined) in 'Putting in the Seed'

The most dominant plosive is /t/, which occurs 25 times. Other voiceless sounds receive emphasis by fronting words. For example, /s/ begins 14 words and occurs 17 times; /p/ begins 6 words and occurs 9 times. In contrast, the voiced equivalents of these sounds are, in total, fewer and less foregrounded. /z/ occurs 10 times but at or near the end of words; while /b/ does begin 8 words and occurs 9 times, /d/ occurs 15 times but never begins a word just as in 'seed' in the title 'Putting in the Seed' and its repeat [10]. Given the overall different proportions of these voiceless and voiced plosives / sibilants, and their different emphases, I would argue we have an onomatopoeic effect of light rainfall ${ }^{17}$.

How can we connect this with the OCPD interpretation in Phase A? We saw in Section 4.2 how unusual 'the watching for' [11] and 'tarnishes with' [12] are. Given also the present tense verbs in the sestet - 'burns' [10], 'comes' [13] - as well as use of the continuous aspect 'shouldering', 'shedding' [14] - and the time taken for the 'schedule' (APA Criterion 1) of germination, the persona must be obsessively observing the earth over a lengthy amount of time. Since the water necessary for germination is very likely to come from rain, how could the persona not get wet at some point with such empirical obsession and detachment? Moreover, the onomatopoeia of light rainfall dovetails with an interpretation that the OCPD sufferer who is a 'Slave to a springtime passion for the earth' [9] -which can be seen as chiming with APA Criterion 3- barely notices the rain. When his partner comes to fetch him [1], they could be fetching him out of the rain. 


\section{PHASE C: GARDENING AND DEPRESSION}

\subsection{OCPD and depression}

From the same website which supplied the APA criteria for diagnosing OCPD, I also found out that there is a relationship between depression and OCPD:

A side effect of OCPD is frequent anxiety or depression, but not usually to the point of a serious disorder (Williams, 2009).

People with OCPD usually have problems with social relationships, which can lead to clinical depression. They tend to focus on organization, perfection, or improvement over fun or social activities... (Williams, 2009) ${ }^{18}$

Phase $\mathrm{C}$ begins with the hunch that perhaps gardening -for that is how I see what the persona of the poem is doing-is recommended for sufferers of depression.

\subsection{Mycobacterium vaccae}

Employing the search terms 'gardening' and 'depression', I discovered on the web that gardening is, indeed, encouraged for the depressed since it can lift their mood. Recent research offers an explanation for this. Consider the following press release for research which was conducted at the University of Bristol, UK:

Getting dirty may lift your mood

Press release issued 2 April 2007

'Friendly' bacteria activated a group of neurons that produce the brain chemical serotonin.

Treatment of mice with a 'friendly' bacteria, normally found in the soil, altered their behavior in a way similar to that produced by antidepressant drugs, reports research published in the latest issue of Neuroscience. ${ }^{19}$

These findings, identified by researchers at the University of Bristol and colleagues at University College London, aid the understanding of why an imbalance in the immune system leaves some individuals vulnerable to mood disorders like depression.

Dr Chris Lowry, lead author on the paper from Bristol University, said: "These studies help us understand how the body communicates with the brain and why a healthy immune system is important for maintaining mental health. They also leave us wondering if we shouldn't all be spending more time playing in the dirt."

Interest in the project arose after human cancer patients being treated with the bacteria Mycobacterium vaccae unexpectedly reported increases in their quality of life. Lowry and his colleagues reasoned that this effect could be caused by activation of neurons in the brain that contained serotonin.

When the team looked closely at the brains of mice, they found that treatment with M. vaccae activated a group of neurons that produce the brain chemical serotonin. The lack 
of serotonin in the brain is thought to cause depression in people, thus M. vaccae's effects on the behavior of mice may be due to increasing the release of serotonin in parts of the brain that regulate $\operatorname{mood}^{20}$.

Playing around in soil, on the above research, leads to contact with mycobacterium vaccae. The research suggests that this can increase serotonin in the brain and thus lead to a lifted mood for those experiencing depression. One might conjecture that this is what is happening to the OCPD / depression suffering persona in 'Putting in the Seed', via his frequent contact with soil (without him necessarily knowing why). Since mycobacterium vaccae live in soil, this allows a reading of 'passion for the earth' [9] where 'the earth' is not functioning as a metonym - that is, it is not standing in for 'nature' - but is literally soil. In other words, the primary reason the persona is in the garden is because contact with the soil cheers him. The 'Love' that 'burns (through the Putting in the Seed)' [10] can be construed (at least in part) as the love for contact with soil and its beneficial effects. Indeed, as previously noted (Section 4.3.1), we never encounter the persona explicitly planting seeds. So, 'Putting in the Seed' seems hardly a title we should trust as being indicative of the primary reason the persona is in the garden.

Let us see how we can mobilise this interpretation via corpus analysis.

\subsection{Corpus-based analysis}

There are 10,056 instances of the phraseology 'passion for' [9] in UKWaC; I found that its top lexical verb collocate is 'share' (357; t-score 18.8). Figure 2 shows 20 randomly generated concordance lines for 'share' + 'passion for'. 'Share a passion for', naturally, presupposes the existence of an established passion which links two or more people. While 'share' is the highest collocate of 'passion for', this does not mean that 'passion for' necessarily has to be used with 'share'. It is, of course, quite possible for one person to say they have a passion for doing something on their own.

That said, in the poem we do have two people seemingly in a relationship and who, presumably, share the same house and garden. There is no evidence to the contrary that they have not both been in the garden before. Moreover, we know that the persona supposes that his partner is capable of having a springtime passion for the earth through use of 'become like me' [8]. Given all this, that 'share' is the highest lexical verb collocate of 'passion for' mobilises the following line of thinking: why would the persona's partner not already share this passion with the persona, regardless of whether they are in a garden or not? It seems odd that the persona's partner would suddenly become like their partner, a slave to a springtime passion for the earth, just by stepping into the garden from the house. Might we then say that the persona is deluding himself here, something to do with the detachment from reality which his OCPD induces? Due to his OCPD and depression, is it not only he who is a 'slave' [9] to a springtime passion for the earth, largely because of the serotonin buzz he gets from contact 
with the soil? Indeed, there is no evidence that the persona's partner has OCPD or depression: they do not need their serotonin level raised through prolonged contact with soil; moreover, they do not want to get wet.

Another way of reading the lack of 'share', or similar meanings, around 'passion for' [9] is in relation to the knowledge that OCPD sufferers have a reluctance to trust a work assignment or task to someone else for fear that their standards will not be met (APA Criterion 6). Recognising that his partner has the capacity for a springtime passion for the earth, the persona does not, in fact, want to share his 'work' [1] with his partner. This is why he is weighing up whether to go inside with his partner (not because he is getting wet as he does not register this). Indeed, OCPD sufferers are likely to prefer asocial activities (see Section 6.1).

Let us see how we can support and further mobilise this combined web and corpusbased performing of the poem via stylistic analysis.

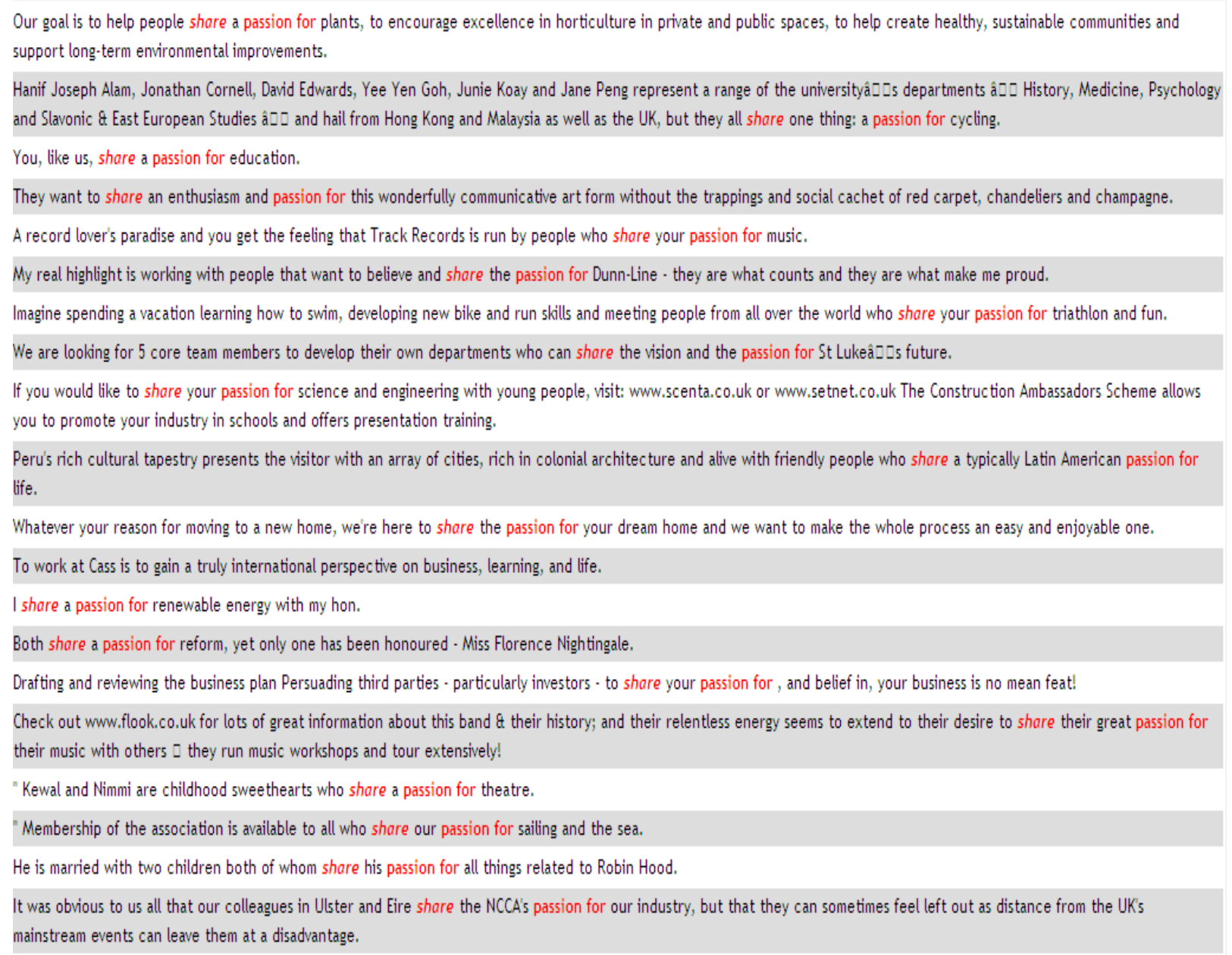

Figure 2. Twenty randomly generated concordance lines for 'share' + 'passion for' 


\title{
6.4. Stylistic analysis
}

\subsection{1. 'Just as'}

Consider the ambiguity with 'just as' in lines 12-14:

\author{
When, just as the soil tarnishes with weed, \\ The sturdy seedling with arched body comes \\ Shouldering its way and shedding the earth crumbs.
}

On the one hand, we can isolate a temporal meaning associated with 'just as': at the same time as the soil tarnishes with weed, the seedling emerges. On the other hand, a comparative meaning is also possible: in the same way as the soil tarnishes with weed, so the earth is tarnished by the seedling emerging. The seedling when it arrives, just like weed (and just like apple blossom), in a sense 'adulterates' the soil for the persona. By this I mean, it is physical contact with soil which is the primary reason for the persona gardening -since it lifts their mood. Naturally, once plants grow, not only does ready access to soil eventually reduce but the horticultural need for physical contact with soil reduces also.

\subsubsection{Pronouns}

There are pronouns in the octet: 'you' [1]; 'we' [2]; 'I' [3]; 'you' x2 [7]; 'you' [8]; 'me'[8]. There are no pronouns in the sestet. As a result, the sestet offers a more impersonal perspective. So, instead of 'our love' or 'love between us' etc, we find the non-pronominalised, capitalised and thus impersonal 'Love' in:

How Love burns through the Putting in the Seed [10].

This gap, this absence of 'our' around 'Love' (or any other grammatical and/or lexical indicator of shared love) supports the corpus-based interpretation I made around 'passion for' [9] that the persona's hyper-enthusiasm for soil contact (in light rain) is (i) not shared by their partner; (ii) the persona prefers to garden on their own.

\subsection{The interpretative multiplicity so far}

On my interpretative multiplicity so far, the persona of the poem has OCPD (the persona fulfils at least four of the American Psychological Association (APA) criteria necessary for diagnosis). He has depression but achieves a serotonin high through regular contact with soil (i.e., with mycobacterium vaccae); his primary reason for being in the garden is contact with soil; he is so obsessed and detached he does not notice the light rain; his partner does not share his passion for soil contact since they do not have OCPD nor depression and do not want to get wet.

It is time to disturb the nature of the phasal movement so far. This is in the interests of inducing further unpredictability into my performance stylistic reading, i.e., in keeping things 
rhizomatic. Firstly, in Phase D, from the vantage of Phases A-C, I critically engage with an existing interpretation of 'Putting in the Seed' that I randomly found on the web; this critical engagement is facilitated by corpus analysis. In Phase E, I use the results of this corpus-based critical engagement to evolve further my performance stylistic reading of 'Putting in the Seed'. In other words, Sections 7 and 8 involve a 'critical-creative' process.

\section{PHASE D: CRITICALLY CONNECTING TO A WEB-BASED INTERPRETATION}

\subsection{Orientation}

I reproduce different excerpts from the interpretation of 'Putting in the Seed' that I found on the $\mathrm{web}^{21}$. Here is the first excerpt:

[Lines 1-2] would seem to reflect the typical lives of American country dwellers in the early twentieth century: the man working outside while his partner tends the house and prepares the dinner.

From the perspective of Deleuze and Guattari, the author evinces a representational attitude through the use of 'reflects'; the critic is not looking at the power of the poem to open up an untimely connection to the past, present or future.

\section{2. 'Nature'}

\section{Beauty of Nature}

[In lines 3-9] the speaker suggests he will find it difficult to tear himself away from the natural world long enough to have his meal, and says they must go quickly into the house before they are both seduced by the beauty of the natural world around them.

The interpretation seems, to me, hyperbolic. Would anyone act in this way if they possessed mental equilibrium ( $\mathrm{cf}$ phases A-C)? Intuitively, part of the reason it is hyperbolic is because the categories 'nature' in the heading and 'natural world' above are too general. Can we really say that the persona is expressing a love of something so general as nature if they are burying apple blossom -the only explicitly flagged contact with organic nature in the poem? (In contrast, my reading related the poem to the much less general 'a love for getting dirty in garden soil'). Having said this, my judgement here that use of 'nature' is too general is ungrounded in evidence. On the reasonable assumption that the persona is in the couple's garden, it would be interesting to see to what extent 'nature' is a common collocate of 'garden'.

In UKWaC, for $n \pm 5$, 'nature' occurs 362 times (t-score 19.0) as a collocate of 'garden'. 'Nature' and 'garden' are, indeed, part of the same discourse. However, 'nature' is not the most common collocate by a long stretch. The most common lexical collocates of 'garden' are 'house' $(4,574$; t-score 67.3$)$, 'rear' $(3,879$; t-score 62.1$)$ and 'front' $(3,497$; $t$ - 
score 58.6). 'Garden', then, is much more commonly talked and written about, in UKWaC, in relation to the home rather than 'nature'. This corpus information problematises, or at least puts into perspective, a rather automatic projection of the general category of 'nature' on to the poem. And, as I show in Section 8, this corpus information helps mobilise interpretation 22 .

In the excerpt which immediately follows on from the previous one, the author moves focus to 'physical love'.

\section{3. 'Love and Sex'}

\section{Love and Sex}

However, a closer examination of the lexical choices leaves the reader in no doubt that a strong sense of physical love runs through this poem as well.

The title of the poem can have two meanings: reflecting the job that the speaker is doing, but also suggesting the physical act of impregnation.

The title of the poem 'Putting in the Seed' suggests impregnation to the interpreter ${ }^{23}$. In line with corpus linguistic principles, I have been taking a phraseological perspective on the poem and so let me do this for the title. What are the most common lexical collocates of the phraseology 'putting in the'? In UKWaC, at $n+5$, they are: 'effort' (48; t-score 6.9), 'work' (29; t-score 5.3) and 'time' (28; t-score 5.2). Thus, 'putting in the' has a semantic preference ${ }^{24}$ for 'effort' / 'time'. Once again, by connecting to corpus evidence, the 'projectional' nature of the interpretation via a general category - 'sex' in the heading above - is illuminated. This is not to say something sexual is not suggested by 'seed' (or elsewhere in the poem). However, a phraseological approach to the language of the poem means that, though 'seed' could suggest semen, we need to appreciate how its meaning in the poem could be mediated by the semantic preference for 'putting in the'.

\subsection{Summary}

The interpretation of 'Putting in the Seed' that I found randomly on the web is unsatisfying on Deleuzean / Guattarian criteria since it does not open up the poem to its interpretative potential. Instead, it remains at a representational level in commenting on what the poem 'reflects' or what it is about; it does not even seek to connect the two different interpretations it offers. Moreover, because 'nature' and 'sex' are rather general categories, their use does not easily mobilise interpretation beyond default, and thus unsurprising, commentary on the poem.

In Section 8, I show how the corpus evidence in this section which I used to criticise this interpretation can be used to evolve my own. In such a way, Phase E below regenerates (rather than plagiarises) the web-based interpretation. 


\section{PHASE E: OCPD, DEPRESSION AND REDUCED SEX DRIVE}

\subsection{Reduced sex drive}

In Section 8, it is the rather general 'sexual' reading in the web-data excerpted in Section 7 that I regenerate. I do so by travelling outside the poem to see whether I can connect 'Putting in the Seed' to a more specific sexual perspective and, simultaneously, to my performance stylistic reading from Phases A-C.

The reader will know from Section 6.1 that depression is a symptom of OCPD. On further web-based research, I found out that depression is associated with reduced sex drive:

...one commonly overlooked symptom of depression...is reduced sex drive, or in more extreme cases, hypoactive sexual desire disorder (HSDD) ${ }^{25}$.

We have a basis for supposing that the persona's OCPD not only leads to depression, but this depression leads to diminishment of libido. Let me now see if this interpretation can be specified / mobilised via the results of the corpus analysis in Section 7.

\subsection{Corpus-based analysis}

While sex would seem to be suggested by 'seed' and elsewhere in the poem, collocations of the phraseology 'putting in the' ['effort' (48; t-score 6.9), 'work' (29; t-score 5.3) and 'time' (28; t-score 5.2)] lead to an interpretation of joylessness in the persona's attitude to his sexual relationship (as well as chiming with the marked conscientiousness of the OCPD sufferer APA Criteria 3 and 4). Consider also collocates for 'shouldering its' [14]: out of the 8 instances of this phraseology in UKWaC, 'responsibility/ies' occurs 5 times. Using only 'shouldering' as a node word, the highest lexical collocates are 'responsibility' (46; t-score 6.8) and 'burden' (34; t-score 5.8). Moreover, the image of the laden 'arched body' [13] can connect with the idea of burden. All this information allows me to develop my performance stylistic reading: not only does the OCPD persona of the poem find their sex life a joyless effort and burden, 'putting in the seed' can be seen as a rather listless way of describing coitus. In other words, the corpus evidence chimes with an interpretation of reduced sex drive.

Recall the corpus evidence in Section 7.2 that the most common lexical collocates of 'garden' are 'house', 'rear', 'front'. The collocation evidence for 'garden' in UKWaC indicates that gardens are talked about most commonly in relation to a house: put another way, it is usual to consider a garden in relation to the home. This corpus evidence mobilises my interpretative performance as follows. While the persona wants to stay in the garden to get his serotonin high, there could be another reason for this: inside the house is associated with his absent sex life, a by-product of the depression associated with OCPD. Staying outside the house for the marked amount of time that must elapse to allow 'the watching for that early 
birth' [11] of a seedling, or to be able to notice the soil just 'tarnishing with weed' [12], might also be construed as an avoidance of his partner and the 'burden' of their sex life.

How might a stylistic analysis connect with this enriched interpretative performance?

\subsection{Stylistic analysis}

\subsubsection{Long vowel to short vowel movement}

Allow me to discuss an internal deviation in the poem which supports and mobilises an interpretation that there are sexual problems in the relationship. This relates to vowel length in the end-rhyme scheme. The vowels in the end-rhymes in lines 1-12 are all 'double-vowels' (/aI/) or long vowels (/i:/ and /3:/). However, in lines 13-14, the rhyme involves the short vowel $/ \Lambda$. One of these short vowels occurs in the orgasmic 'comes', the last word in line 13. An obvious way of symbolising a delirious orgasm would have been to move from short vowels to long vowels in the end-rhymes. Instead, the vowel length scheme in the end-rhymes moves from long to short. All this phonological information connects with the evolving interpretation: attempts at sexual union are somewhat unsuccessful due to the persona's reduced sex drive.

\subsubsection{Lexis}

We previously saw that 'soft petals' $[4,5]$ is repeated twice. The repetition of 'soft' connects with, and further specifies, the reduced sex drive interpretation in suggesting erectile dysfunction - as, indeed, does the entire phraseology 'soft petals fallen' [4] in concert with the movement from long vowels to short in the end-rhymes. (Indeed, might the burying of the 'soft petals fallen' be construed as a symbolic attempt to forget this physical limit?)

For this reading, however, there is a seemingly small inconsistency in the poem. 'Sturdy' in 'the sturdy seedling' [13], as the opposite of soft, may at first glance signal erective proficiency:

The sturdy seedling with arched body comes

Shouldering its way and shedding the earth crumbs.

That said, common collocates around 'shouldering' [14] do rather suggest that achieving 'sturdiness' is an effort or a burden - the apparent contradiction is resolved. Lastly, problems in the relationship are also suggested by the evidence in Section 6.4.2, e.g. the lack of the pronoun 'our' around the capitalised, universal and thus impersonal 'Love' [10].

In sum: in Section 8, I have shown how a corpus-based analysis regenerates the general, and thus rather dead-end, representational 'sex' and 'nature' based interpretations that I found randomly on the web. In turn, this has not only facilitated connection with the flowing interpretative performance of Phases A, B and C, but mobilised it further ${ }^{26}$. Indeed, Phase E has reinforced how an interpretation which works with such general representational 
categories as 'sex' and 'nature' is debilitating on seeing specific, connective possibilities for the poem.

\section{CONCLUSION}

\subsection{Review}

This article has demonstrated a performance stylistic reading. This is an approach, inspired by ideas from Deleuze and Guattari, which connects out to web-based resources for the purposes of generating a singular interpretative performance of a poem. Interpretation with this literacy practice is not concerned with asking 'what is this poem about?', 'what is the poet trying to say? ${ }^{27}$ nor 'what does this poem mean to me?'. Nor does a performance stylistic reading of a poem mean interpretation of the poem itself. This is because the reading is across a series of connections between the poem and a number of outsides, a reading which uses these connections to perform the poem by filling in its personas and scenarios in specific and surprising ways. And, because the emphasis is on the individuality of the interpretative travelling and filling-in, performance stylistics does not seek to do the following: form a universal perspective on the human condition from the particulars of the poem - as is often the case in traditional literacy practices around poetry.

In phasing analysis / interpretation rhizomatically, my evolving interpretation in effect became a multiplicity of elements (OCPD, germination, gardening and depression, depression and reduced sex drive, relationship difficulties in a couple because one partner has a personality disorder) which is greater than the sum of its parts. Looking at interpretation in terms of a multiplicity helps to circumvent an unrealistic reading of a poem which does not evoke the plural dimensions to life. Moreover, it helps to avoid closing down creative options in interpretation. Given the ever expanding world-wide web, there is potentially no end point for interpretation using the procedure of this article. Moreover, phasing analysis / interpretation has the advantage of staggering linguistic description; too much stylistic analysis early on, I would argue, can stunt the prospect of generating a singular interpretative performance because of the difficulties from shaking off default associations with linguistic representations ${ }^{28}$.

To reiterate from the introduction, stylistic analysis is a necessary centripetal force in performance stylistics rather than a choice. One cannot do this kind of poetry interpretation without linguistic analysis of a poem's structural elements since this centripetal analysis is needed to connect up the web-based centrifugal phases via description of the patterns of the poem. This not only connects interpretative elements from the centrifugal phases into the poem's language patterns, but this act of connection crucially mobilises interpretation also. Since the analyst needs to be guided by the idiosyncratic patterns of the poem in the forging 
of these connections, there is a certain unpredictability to the final interpretation which helps the progressing of a singular interpretative performance. In contrast, the use of corpus analysis is not a necessary component of performance stylistics. Corpus analysis can be used in a less comprehensive manner than the stylistic analysis, used at different points to mobilise interpretation where this works. Furthermore, since the initial web-based connections made with the poem are based, as far as is possible, in fact / current research, this means that, when interpretation is progressed through use of (corpus) stylistic analysis, it is grounded in fact / current research rather than mere speculation.

\section{2. 'What is this poem about?'}

Since novels, plays and films commonly have explicit plots and characters, asking the question, 'what is this novel / play / film about?' is often apposite. In contrast, much poetry (particularly many lyric poems of the last hundred years or so) does not contain explicit characters and plot; it is common for poetry to feature a much greater degree of obliqueness and suggestiveness than in many novels, plays and films. Since making sense of many poems is dependent, to a large degree, on how the reader fills in the 'gaps', asking 'what is this poem about?' does not always seem to me to be so apposite a question, or at least a completely apposite question. Indeed, this question could limit the interpretative potential of the poem. Asking 'what is 'Putting in the Seed' about?' is, I think, unlikely to lead to a response that the persona of the poem has OCPD and regularly gardens because of the side-effect condition of depression etc. This is because the very posing of this question restricts the possibilities of a reader opening out the poem to a new set of connections which could then help perform the poem in this way. Naturally, there are limitations to the validity of making connections between a poem and things outside of it; for a connection to be valid, there needs to be an empirical basis in the poem for forming a semantic link with something outside. For example, I began my performance stylistic reading of 'Putting in the Seed' from the suggestion that the poem's persona has a certain obsession with burying apple blossom given they have to be fetched in for supper and question if they will be capable of leaving their work.

\subsection{Divergence in interpretative performances}

Due to the vastness of the web, interpretative travels initiated by a poem are likely to diverge markedly for different interpreters; indeed, the obliqueness and suggestiveness of much poetry make it likely that the web searches triggered from reading a poem will vary. And, because of this divergence, and also because a performance stylistic reading is phased, how stylistic analyses and corpus analyses will be used to support / mobilise the web-based element of the reading is likely to vary for different interpreters. By its very nature, there cannot be one definitive, performance stylistic reading of a poem. But, can all poetry be put to 
work in this way? Lyric poetry which has openness in its textuality is more likely to be productive for performance stylistic ends, for allowing movement through and around the poem, than other forms ${ }^{29}$.

No doubt there are other possible sequences and hook-ups between Deleuze / Guattari and (corpus) stylistics. The image of the rhizome is anything but inflexible ${ }^{30}$. Finally, I hope I have shown how a performance stylistic reading of a poem is a pleasurable, creative challenge for the reader: putting a poem to work in order to produce, in their own unique way, a series of dynamic connections with a variety of outsides, pulling these into the unpredictably mobilising machine of the corpus and then into the specific patterns of the poem, evolving a rhizomatic riff, an untimely and singularly performative journey.

\section{ACKNOWLEDGEMENTS}

Many thanks to Guy Cook, Rob Pope, Philip Seargeant, Joan Swann and Catherine Williams for commenting on previous drafts.

\section{NOTES}

1. 'The best craftmanship always leaves holes and gaps in the works of the poem, so that something that is not in the poem can creep, crawl, flash, or thunder in.' Dylan Thomas (quoted in Leech, 1969: 227)

2. Frost (1995:120).

3. This process could work, of course, with a paper-based encyclopedia, moving rhizomatically from one entry to another. However, the web is so much better for this process since, given its size, it affords greater potential for movement variation, not only from website to website, but from one different text type to another.

4. A 'Deleuze and Guattari machine' is not the same as a mechanism since the latter is organised for a particular purpose (e.g. a clock is organised for telling the time). See Deleuze and Guattari (2004).

5. This is not to say that Deleuze and Guattari set up a dichotomy of being and becoming; for Deleuze and Guattari, being is part and parcel of becoming. Rob Pope indicates this via his neographism, 'human be(com)ing' (Pope, 2005: 113).

6. This does not necessarily mean that an untimely interpretation needs to relate an old work of literature to the present day. An untimely perspective on 'Putting in the Seed' could, potentially, link it back to 1916. But, it would show, in some way, how the poem renews existing appreciation of that context.

7. The UK Web as Corpus (UKWaC) was built in 2007. It consists of around 1.5 billion words from world-wide-web sites with a UK internet domain name. It contains a wide variety of topics and genres. Since the aim was to build a corpus of British English, only UK Internet domains were included (see Ferraresi et al., 2008).

8. http://www.sketchengine.co.uk/

9. http://www.brainphysics.com/oc-personality.php [Accessed June 2012]

10. http://www.brainphysics.com/oc-personality.php [Accessed June 2012]

11. http://www.brainphysics.com/oc-personality.php [Accessed June 2012]

12. OCPD is not to be confused with 'Obsessive Compulsive Disorder' (OCD). OCD is an anxiety disorder (APA, 2000) not a personality disorder. Someone with OCD is focused on particular 
obsessions, such as repeated hand-washing, which distress the sufferer. In contrast, someone with OCPD is not distressed by their abnormality. See http://www.brainphysics.com/oc-personality.php [Accessed June 2012].

13. There are two well-known forms of sonnet, each with different rhyme schemes. The Shakespearean sonnet is end-rhymed $a-b-a-b, c-d-c-d, d-e-d-e, g-g$, where these letters refer to a particular vowel (+consonant(s)) at the end of a line. The other well-known form of sonnet is the Petrarchan or Italian sonnet. The rhyme scheme of the Petrarchan octet is usually $a-b-a-b-a-b-a-b$. For the sestet, there are different possibilities, e.g: $c-d-e-c-d-e, c-d-c-c-d-c$ and $c-d-c-d-c-d$. Frost uses the following rhyme scheme $a-b-a-b-a-b-a-b, c-d-c-d-e-e$.

14. http://en.wikipedia.org/wiki/Germination [Accessed June 2012]

15. Henceforth, the first number in curved brackets refers to the frequency of a collocate and the second number the t-score for the collocation).

16. I include the voiceless affricate $/ \mathrm{t} /$.

17. To check this, the reader may want to listen to: http://www.youtube.com/watch?v=1pSyYhRYeIM\&feature=related [Accessed June 2012].

18. http://www.brainphysics.com/oc-personality.php [Accessed June 2012]

19. See Lowry et al. (2007).

20. http://www.bristol.ac.uk/news/2007/5384.html [Accessed June 2012]

21. See: http://www.suite101.com/content/robert-frosts-putting-in-the-seed-a33831 [Accessed June 2012]

22. The next chunk is not part of the web-based interpretation but an advert with a hyperlink (underlined) that appears within it:

How To Study A Poem

Whether you are reading a poem for pleasure, or simply trying to pass an exam, these helpful hints should allow you to get to grips with what the poet is trying to say.

With 'what the poet is trying to say', we have more un-Deleuzean, representational discourse. Such pedagogy would push us in the direction of a timely rather than an untimely interpretation.

23. 'Not so barren quite' (line 5) rather protrudes in an interpretation around 'impregnation' in suggesting only a little fertility.

24. 'Semantic preference is the restriction of regular co-occurrence to items which share a semantic feature, for example that they are all about, say, sport or suffering' (Sinclair, 2004: 142).

25. http://www.everydayhealth.com/sexual-health/depression-and-hypoactive-sexual-desiredisorder.aspx [Accessed June 2012]. This website does not carry a reference for an academic source. However, it is validated by Pat F. Bass II, MD, MPH, an associate professor of medicine and pediatrics at Louisiana State University Health Services Center-Shreveport.

26. As an alternative, one could use comments from a web discussion forum to engage with critically-creatively. Here, for example, is a comment from a randomly discovered forum discussing 'Putting in the Seed' which offers a sexual interpretation:

Frost is a deep poet. "Putting in the seed" has definatley got a sexual agenda, the title alone conveys this. "if i leave off burrying the white soft petals" seems to be Frost describing love making outside and the sheer weight buries the soft white petals. This may be related to Frost's mistress. Definatley a light hearted poem which uses love making as a metaphor to convey his love for nature. Good luck in your exams everyone...XXX.

http://www.americanpoems.com/poets/robertfrost/12084/comments/2 [Accessed June 2012].

27. In not taking the writer's intentions into account, performance stylistics accords with Barthes' 'Death of the Author' thesis (Barthes, 1967). 
28. The interpretative performance I have generated is, naturally, one of many possibilities. I was raised as a Christian: for me, 'fallen', 'the apple tree', 'garden', 'passion' resonate biblically: the fall, tree of knowledge, garden of Eden / garden of Gethsemane, the passion respectively. On this train of thought, might 'shouldering' connect with Christ's shouldering of a wooden cross as part of the Passion? Then again, these are ideas related to my being and not becoming - I need to go beyond what I know already.

This website - http://www.bbc.co.uk/news/uk-10905070 [Accessed June 2012] - tells me that 'love' and 'seed' have the same etymological root in Arabic and that this is mentioned in the Koran. Especially as these words occur in the same line (10) in 'Putting in the Seed', possibilities for a bi-faith rhizome in and around the poem, thus, present themselves, one which could become both critical and creative.

29. As a coda, one might argue that what we regard as a literary or valuable poem on Deleuzean / Guattarian criteria is one which has the potential to do the following: set off the greatest number of readers to generate unique rhizomes of creative, connective possibilities.

30. And the procedure I have demonstrated is protean too. A performance stylistics reading of a poem which consists of three phases is manageable for a short undergraduate project (in my case, Phases A-C come to around 3, 700 words). If the project is longer in scope, then the critical-creative Phases D-E could also be accommodated (the substantive parts being around 1,700 words in my case). A short assignment could just involve a corpus-based, critical engagement with an existing web-based interpretation along the lines of Phase D.

\section{REFERENCES}

Adolphs, S. \& Carter, R. (2002). Corpus Stylistics: point of view and semantic prosodies in To the Lighthouse. Poetica, 58, 7-20.

American Psychological Association (APA) (2000). Diagnostic and statistical manual of mental disorders (4th ed., text revision). Washington, DC.

Barthes, R. (1977/1967). The Death of the Author. In R. Barthes, Image, Music, Text, essays selected and translated by Stephen Heath (pp. 142-148). London: Fontana.

Biber, D. (2012). Corpus linguistics and the study of literature: back to the future? Scientific Study of Literature, 1(1), 15-23.

Culpeper, J. (2009). Keyness: Words, parts-of-speech and semantic categories in the character-talk of Shakespeare's Romeo and Juliet. International Journal of Corpus Linguistics, 14, 29-59.

Deleuze, G. (1983/1962). Nietzsche and Philosophy, trans. H. Tomlinson. London: Athlone.

Deleuze, G. (1995). Negotiations 1972-1990 (M. Joughin, Trans.). New York: Columbia University Press.

Deleuze, G. (2004/1968). Difference and Repetition (P. Patton, Trans.) London: Continuum.

Deleuze, G. \& Guattari, F. (1987/1980). A Thousand Plateaus, trans. Brian Massumi. London: Athlone.

Deleuze, G. \& Guattari, F. (2004/1972). Anti-Oedipus. London: Continuum.

Ferraresi, A., Zanchetta, E., Baroni, M. \& Bernardini, S. (2008). Introducing and evaluating UKWaC. In S. Evert, A. Kilgarriff \& S. Sharoff (Eds.), Proceedings of the $4^{\text {th }}$ Web as Corpus Workshop: Can we beat Google? (pp. 47-54). Marrakech, Morocco.

Fischer-Starcke, B. (2010). Corpus Linguistics in Literary Analysis: Jane Austen and Her Contemporaries. London: Continuum.

Frost, R. (1995/1916). Putting in the Seed. In Poirier, R. and Richardson, M. (Eds.) Robert Frost Collected Poems, Prose and Plays (p. 120). New York: The Library of America.

Hoover, D. (2002). Frequent word sequences and statistical stylistics and authorship attribution: an empirical investigation. Literary and Linguistic Computing, 17, 157-180. 
Hunston, S. (2001). Colligation, Lexis, Pattern, and Text. In M. Scott and G. Thompson (Eds.), Patterns of Text: In Honour of Michael Hoey (pp. 13-33). Amsterdam: John Benjamins.

Hunston, S. (2002). Corpora in Applied Linguistics. Cambridge: Cambridge University Press.

Hunston, S. (2010). Corpus Approaches to Evaluation: Phraseology and Evaluative Language. Abingdon: Routledge.

Jones, S. \& Sinclair, J. (1974). English lexical collocations. Cahiers de Lexicologie, 24, 15-61.

Leech, G. (1969). A Linguistic Guide to English Poetry. Harlow: Longman.

Louw, W. (1993). Irony in the text or insincerity in the writer? The diagnostic potential of semantic prosodies. In M. Baker, G. Francis and E. Tonini-Bonelli (Eds.), Text and Technology (pp. 157176). Amsterdam: John Benjamins.

Lowry, C., Hollis, J., de Vries, A, Pan, B., Brunet, L., Hunt, J, Paton, J., van Kampen, E, Knight, D., Evans, A., Rook, G. \& Lightman, S. (2007). Identification of an immune-responsive mesolimbocortical serotonergic system: Potential role in regulation of emotional behavior. Neuroscience, 46(2-5), 756-772.

McGlashan, T., Grilo C., Sanislow, C., Ralevski E., Morey, L., Gunderson, J., Skodol, A., Shea, M., Zanarini, M., Bender, D., Stout, R., Yen, S. \& Pagano, M. (2005). Two-year prevalence and stability of individual DSM-IV criteria for schizotypal, borderline, avoidant, and obsessivecompulsive personality disorders: toward a hybrid model of axis II disorders. American Journal of Psychiatry, 162(5), 883-889.

McIntyre, D. \& Walker, B. (2010). How can corpora be used to explore the language of poetry and drama? In M. McCarthy, A. O'Keeffe (Eds.), The Routledge Handbook of Corpus Linguistics (pp. 516-530). Abingdon: Routledge.

Mahlberg, M. (2007). Clusters, key clusters and local textual functions in Dickens. Corpora, 2(1), 131.

O'Halloran, K.A (2007a). The subconscious in James Joyce's 'Eveline': a corpus stylistic analysis that chews on the 'Fish hook'. Language and Literature, 16(3), 227-244.

O'Halloran, K.A (2007b). Corpus-assisted literary evaluation. Corpora, 2(1), 33-63.

Pope, R. (2003). Re-writing texts, re-constructing the subject: work as play on the critical-creative interface. In T. Agathocleous and A. Dean (Eds.), Teaching Literature: A Companion (pp. 10524). London: Palgrave Macmillan.

Pope, R. (2005). Creativity: Theory, History, Practice. Abingdon: Routledge.

Raven, P, Evert, R. \& Eichhorn, S. (2005). Biology of Plants, 7th Edition. New York: W.H. Freeman and Company Publishers.

Romaine, S. (2010). 19th Century Key Words, Key Semantic Domains and Affect: "In the Rich Vocabulary of Love 'Most Dearest' be a True Superlative". Studia Neophilologica, 82(1), 12-48.

Sinclair, J. (2004). Trust the Text: Language, Corpus and Discourse. London: Routledge.

Stubbs, M. (2005). Conrad in the Computer: Examples of Quantitative Stylistic Methods'. Language and Literature, 14(1), 5-24.

Thornborrow, J. \& Wareing, S. (1998). Patterns in Language: An Introduction to Language and Style. London: Routledge.

Toolan, M. (2006). Top keyword abridgements of short stories: a corpus linguistic resource? Journal of Literary Semantics, 35(2), 181-194.

Williams, M. (2009). Obsessive-Compulsive Personality Disorder: When Everything Has to Be "Just Right". OCD Resource Center of Florida, http://www.ocdhope.com/oc-personality-disorder.php [Accessed June 2012]. 